\title{
EXTRACTION OF URANIUM USING ALAMINE 336 IN KEROSENE FROM SULFATE SOLUTION OF ABU- HAMATA SANDY CLAYSTONE ORE SAMPLE, SOUTHWESTERN SINAI, EGYPT
}

\author{
Abd El Wahab, G.M. ${ }^{1}$, Abdellah, W.M. ${ }^{1}$ and El-Shahat, M.F ${ }^{2}$ \\ 1- Nuclear Materials Authority, P.O Box 530, El-Maadi, Cairo, Egypt. \\ 2- Chemistry department, Faculty of Science, Ain Shams University, Cairo, Egypt.
}

\begin{abstract}
The present study is concerned with the feasibility of using organic solvent, Alamine $_{336}$ in kerosene to extract $U$ from sulfate leach liquor of Abu-Hamata sandy clay stone ore sample. The prepared sulfate leach liquor assays $0.45 \mathrm{~g} / \mathrm{L}$ of $\mathrm{U}$ with achieved leaching efficiency of $98.9 \%$. The obtained results indicate that $\mathrm{U}$ extraction efficiency depends mainly on Alamine 336 concentration, strongly influenced by $\mathrm{pH}$ value, contact time and the organic / aqueous $(\mathrm{O} / \mathrm{A})$ ratio.

Uranium in the organic phase was stripped using a solution of $1 \mathrm{M} \mathrm{NaCl}$ acidified with $0.2 \mathrm{M} \mathrm{H}_{2} \mathrm{SO}_{4}$ with an achieved stripping efficiency of $93.9 \%$ at $\mathrm{A} / \mathrm{O}$ ratio of $1 / 1$ and shaking time of $5 \mathrm{~min}$. Not less than $99 \%$ of $\mathrm{U}$ in the obtained $\mathrm{U}$ rich strip solution was directly precipitated using $\mathrm{H}_{2} \mathrm{O}_{2}$ solution to produce the final pure product of $\mathrm{U}_{3} \mathrm{O}_{8}$.
\end{abstract}

Key words: Uranium, Extraction, Alamine336, Sandy Claystone.

\section{Introduction}

The global $\mathrm{U}$ demand (the main source to generate the atomic power) is expected to grow up in the next years as cheap and more quantity of the electricity to full fill the country demands. Sandstone deposits are considered as one of seven conventional $U$ resources with the highest reserve in the world, Dahlkamp, (1980). Abu Hamata clay stone rock fancies of Um Bogma formation which occurs at Abu Zeneima area, Southwestern Sinai, Egypt is considered indeed one of the most important occurrence of $U$ beside some associated economic metal values e.g. REEs, $\mathrm{V}, \mathrm{B}, \mathrm{Zn}, \mathrm{Cu}, \ldots$ etc. Al Shami, (2003) recorded some trace elements in the claystone rocks such as $\mathrm{Ba}$ and $\mathrm{U}$ at Abu Hamata area. Field study observation revealed the presence of minerals of $\mathrm{U}, \mathrm{Cu}$ as well as Fe-Mn at the area under study. 
In addition, various ore minerals have actually been identified in the various rock units of Abu Zeneima as has been reported by Dabbour and Mahdy (1988); Hussein et al. (1992); Amer (1993 \&1997); Abdel Momen et al. (1997). The main identified secondary $U$ minerals include uranophane, betauranophane, carnotite, kasolite, meta-torbernite, meta-uranocircite and bassetite.

Sulfuric acid is the predominate agent used for $\mathrm{U}$ dissolution because of its relatively low cost, wide availability and shorter leaching time. $U$ is effectively recovered from the sulfate leach liquor through two mainly techniques namely; ion exchange and solvent extraction, Ritcy and Ashrock (1982). Moreover Amer (1997) and Ghonaim et al., (2004) have studied $\mathrm{H}_{2} \mathrm{SO}_{4}$ acid leaching of Abu Zeneima gibbsite ore materials for recovering $\mathrm{Al}$, $\mathrm{Zn}, \mathrm{U}$ and $\mathrm{Cu}$.

In recent years organic solvents are the most popular choice for $\mathrm{U}$ extraction and purification circuits. The phosphorous based extractants namely; tributyl-phosphate (TBP), di- (2-ethylhexyl) phosphoric acid (D2EHPA), 2ethylhexyl phosphonic acid, mono-2-ethylhexyl ester (PC 88A), tri-n-octylphosphine oxide (TOPO or Cyanex 923) and bis (2, 4, 4-trimethylpentyl) phosphonic acid (Cyanex 272) were used for U(VI) extraction from various acidic solutions. Tertiary amines of the general formula $\mathrm{R}_{3} \mathrm{~N}$, where $\mathrm{R}$ (alkyl group containing eight or ten carbon atoms) are commonly used in acid leach circuits.

Kumar, et al. (2010) studied the recovery of $U$ and its separation from $\mathrm{V}$ in synthetic sulfate leach liquor. While $\mathrm{NH}_{4} \mathrm{Cl}$ solution was used as stripping agent. In addition, selective separation of $\mathrm{U}$ from the associated REEs and Th in monazite sulfate leach liquor was attained by Amaral, et al., (2010). The extraction of $95 \%$ of $U$ from diluted sulfate leach liquor that contains high concentrations of REEs was conducted by using 2\% (v/v) Alamine 336. A stripping efficiency of $98 \%$ from the loaded $\mathrm{U}$ was attained by $1 \mathrm{NaCl}$ acidified with $0.2 \mathrm{M} \mathrm{H}_{2} \mathrm{SO}_{4}$, Ramadevi, et al. (2012).

The present paper is concerned with the concentration of $U$ from Abu-Hamata sandy claystone sulfate leach liquor rich with REEs via organic solvent extraction technique. Alamine 336 was used for this purpose, where pure $\mathrm{U}$ product was attained from the concentrated $\mathrm{U}$ strip solution via direct precipitation using $\mathrm{H}_{2} \mathrm{O}_{2}$.

\section{Experimental}

Experimental work requires the investigation of both mineralogical and chemical constituents of the representative technological sample as well as the processing procedures (leaching \& extraction) of the metal values. 


\section{Investigation of mineralogical and chemical constituents}

To identify the mineralogical composition of Abu Hamata sandy clay stone ore sample, a $1 \mathrm{~kg}$ weight of the working bulk sample ground to a mesh size of -60 was carefully washed with tap water several times to remove the slimes. After dryness and using a set of sieves ranging from 500 to $100 \mu \mathrm{m}$, different portions of different volume size ranging from 35 to 140 mesh were obtained. The latter under heavy liquid separation using bromoform (sp.gr. 2.84), were separated to different light and heavy fractions. Each fraction was isodynamically separated at $(0.2,0.5,1.0$ and 1.5 Amp.) using Frantz isodynamic separator. Several different grains from each fraction were picked up by using binuclear microscope. The latter were investigated using X-ray diffraction, (XRD), analysis technique to identify the present minerals.

For chemical composition, a weight of $1 \mathrm{~g}$ portion ground to a mesh size of 200 from the working sample was digested with the acid mixture, $\left(\mathrm{H}_{2} \mathrm{SO}_{4}\right.$, $\mathrm{HCl}, \mathrm{HNO}_{3}$ and $\mathrm{HF}$ ) for the complete dissociation and closed up to a measuring volume of $100 \mathrm{~mL}$. The latter was subjected to different analytical techniques to show its chemical composition. However, the major oxides such as: $\mathrm{Fe}_{2} \mathrm{O}_{3}, \mathrm{Al}_{2} \mathrm{O}_{3}, \mathrm{MgO}$ and $\mathrm{CaO}$ are classically estimated by wet chemistry, Shapiro and Brannock (1975), while the trace elements e.g. V, B, $\mathrm{Zn}, \mathrm{Cu}$, $\mathrm{Pb}, \mathrm{Ni}, \mathrm{Co}$, etc. were estimated by using the flam atomic absorption spectrophotometer (FAAS) Unicam 969.

On the other hand, UV-vis spectrophotometer (Shemadzu 610) is used for the quantitative analysis of the total REEs using Arsenazo III at $\lambda_{654} \mathrm{~nm}$, Marczencko (2000). $U$ is analyzed via oxidometric titration method against $\mathrm{NH}_{4} \mathrm{VO}_{3}$, Mathew, et al., (2009). For $\mathrm{Si}$ analysis a small portion weighted $0.1 \mathrm{~g}$ of the fine ground ore sample is fused with $1 \mathrm{~g}$ portion of $\mathrm{NaOH}$ pellets in a nickel crucible for $20 \mathrm{~min}$ directly on Bunsen flame. The fused matrix is dissolved with $\mathrm{HCl} \mathrm{1:1}$ and closed up to a measuring volume of $250 \mathrm{~mL}$ where Si estimated by using UV-vis spectrophotometer (Shemadzu 610) at $\lambda$ $640 \mathrm{~nm}$, Marczencko (2000). In the mean time, the final product of $U$ is identified by using both of XRD and SEM-EDAX analysis techniques. While the $\mathrm{pH}$ values of all solutions are measured with a DM-21pH meter (Digimed, S. Paulo, Brazil).

\section{Preparation of working sulfate solution.}

The working sulfate solution of the studied ore sample was prepared via acidic agitation leaching of $1 \mathrm{~kg}$ weight by using $5 \% \mathrm{H}_{2} \mathrm{SO}_{4}$ at a solid/ liquid, $(\mathrm{S} / \mathrm{L})$ ratio of $1 / 2$ and stirring time of $1 \mathrm{~h}$, while the leaching temperature was kept at $75^{\circ} \mathrm{C}$. After filtration and washing with distilled $\mathrm{H}_{2} \mathrm{O}$, the final volume of the prepared sulfate leach liquor was 4 liters and its $\mathrm{pH}$ value was found to 
attain $\mathrm{pH}$ 0.5. The latter was directed to solvent extraction unit to recover its U content.

\section{Optimization of Alamine 336 effective extraction parameters}

Uranium in the prepared sulfate leach liquor was extracted by using Alamine 336 in Kerosene. The diluted neutral Alamine 336 was pretreated with $0.2 \mathrm{M} \mathrm{H}_{2} \mathrm{SO}_{4}$ for $10 \mathrm{~min}$ at an $\mathrm{O} / \mathrm{A}$ ratio of $1 / 1$ to convert to its suitable extractant sulfate form. The relevant effective extraction parameters such as: extractant concentration, $\mathrm{pH}$ value, contact time and phases volume ratios $(\mathrm{O} / \mathrm{A})$ were investigated to optimize the loading $\mathrm{U}$ process. The type and concentration of the stripping solution and phases ratios $(\mathrm{O} / \mathrm{A})$ were studied to optimize the U stripping process.

\section{Preparation of $\mathbf{U}$ pure product}

The strip $\mathrm{U}$ concentrated solution was adjusted to direct precipitation process by using $\mathrm{H}_{2} \mathrm{O}_{2}$ solution at $\mathrm{pH} 2$. After filtration and washing, the precipitated $\mathrm{U}$ cake was ignited at $850^{\circ} \mathrm{C}$ for $1 \mathrm{~h}$ to be crystallized. The produced $\mathrm{U}_{3} \mathrm{O}_{8}$ was washed, dried and then identified using XRD analysis technique and chemically analyzed to estimate its final purity, Bhowmik et al. (2009).

\section{Results and discussion}

\section{Mineralogical and chemical composition of working ore sample}

XRD analysis data represented by Fig. (1) emphasized the presence of Renardite $\mathrm{U}$ mineral $\left[\mathrm{Pb}\left(\mathrm{UO}_{2}\right)_{2}\left(\mathrm{PO}_{4}\right)_{2} \cdot 8 \mathrm{H}_{2} \mathrm{O}\right]$. The latter has a wide distribution in $1.5 \mathrm{Amp}$. of non magnetic fraction with lesser extent in 1.0A magnetic fractions. $U$ in such secondary $U$ minerals was characteristic by its easier dissolution, thus the leachability of $U$ was very easy and applicable. Renardite, is a yellow mineral consists of hydrous basic $\mathrm{Pb}$ uranyl phosphate with chemical composition as $\mathrm{UO}_{2}$ of $64.62 \mathrm{wt} . \%, \mathrm{P}_{2} \mathrm{O}_{5}$ of 8.49 wt. $\%, \mathrm{H}_{2} \mathrm{O}$ of $9.7 \mathrm{wt} . \%$ and $\mathrm{PbO}$ of $13.35 \mathrm{wt} . \%$. It is a rare secondary uranyl mineral formed by alteration of uraninte $\left(\mathrm{UO}_{2}\right)$ or earlier-formed secondary uranium minerals and it is characterized by the ease of its dissolution.

Finally, it was quite important to mention herein that, the mineralogical study proved that, the working sandy clay stone ore material has no identified mineral grains for either REEs, B or V although their relative high content in the study ore sample. This is probably due to their adsorption upon the clay mineral, [montmorillonite]. Complete chemical analysis of the studied sandy clay stone ore sample, Table (1) revealed that it is mainly composed of $\mathrm{SiO}_{2}$ which represents the main constituent (55.6\%) beside $\mathrm{Al}_{2} \mathrm{O}_{3}(12.70 \%)$ and $\mathrm{Fe}_{2} \mathrm{O}_{3}(9.81 \%) . \mathrm{K}_{2} \mathrm{O}$ as well as $\mathrm{MgO}$ represent the much lesser constituents of 
the study ore material. Moreover, the sample was found to contain trace amounts of $\mathrm{TiO}_{2}, \mathrm{Na}_{2} \mathrm{O}, \mathrm{CaO}$ and $\mathrm{P}_{2} \mathrm{O}_{5}$.

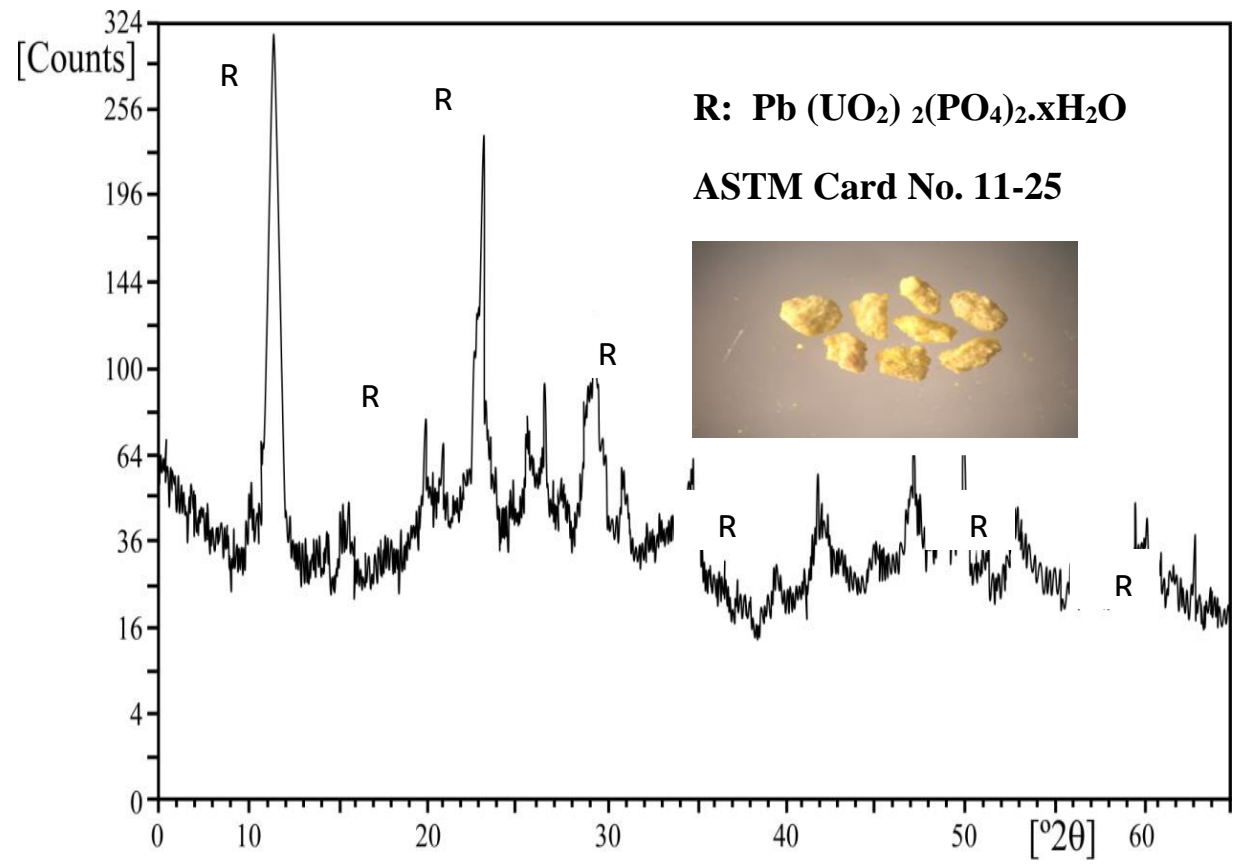

Fig. (1): XRD pattern of Renardite mineral.

Table (1): Chemical composition of Abu-Hamata sandy claystone sample.

\begin{tabular}{cccc}
\hline Major oxides & Wt., \% & Trace elements & Conc., ppm \\
\hline \hline $\mathrm{SiO}_{2}$ & 55.6 & $\mathrm{U}$ & 1830 \\
$\mathrm{Al}_{2} \mathrm{O}_{3}$ & 12.7 & REEs & 1375 \\
$\mathrm{Fe}_{2} \mathrm{O}_{3}$ & 9.81 & $\mathrm{~V}$ & 1750 \\
$\mathrm{~K}_{2} \mathrm{O}$ & 3.7 & $\mathrm{~B}$ & 1100 \\
$\mathrm{MgO}$ & 2.0 & $\mathrm{Cr}$ & 833 \\
$\mathrm{TiO}_{2}$ & 1.0 & $\mathrm{Cu}$ & 650 \\
$\mathrm{Na}_{2} \mathrm{O}$ & 0.92 & $\mathrm{Ba}$ & 448 \\
$\mathrm{CaO}$ & 0.68 & $\mathrm{Zn}$ & 345 \\
$\mathrm{P}_{2} \mathrm{O}_{5}$ & 0.21 & $\mathrm{Co}$ & 46 \\
$\mathrm{MnO}$ & 0.04 & $\mathrm{Ni}$ & 64 \\
${ }^{*} \mathrm{~L} . \mathrm{O} . \mathrm{I}$ & 11.1 & $\mathrm{Ga}$ & 25 \\
$\mathrm{Cl}{ }^{-}$ & 0.7 & & \\
$\mathrm{SO}_{4}{ }^{2-}$ & 0.043 & & \\
Total & 98.503 & &
\end{tabular}

It is worthy to mention herein that the high contents of $\mathrm{SiO}_{2}, \mathrm{Al}_{2} \mathrm{O}_{3}$ together with loss of ignition $(11.1 \%)$ and $\mathrm{K}_{2} \mathrm{O}$ reflect the sandy clay nature of the studied ore material. The loss was found to be distributed between humidity (4.6\%), water of crystallization (3.2\%) as well as organic matter and $\mathrm{CO}_{2}$ 
(3.3\%). The high moisture as well as the high crystalline $\mathrm{H}_{2} \mathrm{O}$ content are attributed to the presence of montmorillonite mineral which has the tendency to absorb $\mathrm{H}_{2} \mathrm{O}$ and able to swell. On the other hand, the chemical composition of the studied ore material shows the presence of considerable concentrations of some valuable trace elements e.g. U, V, REEs and B.

\section{Working sulfate solution.}

Table (2) shows the chemical composition of the prepared working sulfate solution. This table reveals that there are several interfering metal ions with high concentrations especially $\mathrm{SO}_{4}{ }^{2-}$ and $\mathrm{Cl}^{-}$. These metal ions inhibited extraction process of uranyl sulfate complex, $\left[\mathrm{UO}_{2}\left(\mathrm{SO}_{4}\right)_{3}{ }^{4-}\right]$ when ion exchange method is applied, Merrit (1971), Ritcy, et al., (1993) and Mackenzie (1997). Thus, the suitable choice for $U$ extraction from the prepared sulfate solution will be done using organic solvents. For this purpose, Alamine 336 in kerosene would be used to recover $\mathrm{U}$.

Table (2): Chemical constituents of the working sulfate solution.

\begin{tabular}{cc}
\hline Metal ion & Conc., g/L \\
\hline \hline $\mathrm{SO}_{4}{ }^{2-}$ & 26 \\
$\mathrm{Cl}^{-}$ & 2.34 \\
$\mathrm{REES}$ & 0.32 \\
$\mathrm{U}$ & 0.45 \\
$\mathrm{Fe}$ & 0.88 \\
$\mathrm{~V}$ & 0.05 \\
$\mathrm{Ca}$ & 0.04 \\
\hline
\end{tabular}

\section{Mechanism of loading process}

The mechanism of the loading process of the present uranyl sulfate complex $\left[\mathrm{UO}_{2}\left(\mathrm{SO}_{4}\right)_{3}\right]^{4-}$ using the activated form of Alamine 336 is illustrated in equations:

$$
\begin{aligned}
2 \mathrm{R}_{3} \mathrm{~N}+2 \mathrm{H}_{2} \mathrm{SO}_{4} & \longrightarrow 2\left(\mathrm{R}_{3} \mathrm{NH}\right)_{2} \mathrm{SO}_{4} \\
2\left(\mathrm{R}_{3} \mathrm{NH}\right)_{2}\left(\mathrm{SO}_{4}\right)+\mathrm{UO}_{2}\left(\mathrm{SO}_{4}\right)_{3}{ }^{4-} & \longrightarrow\left(\mathrm{R}_{3} \mathrm{NH}\right)_{4} \mathrm{UO}_{2}\left(\mathrm{SO}_{4}\right)_{3}+2 \mathrm{SO}_{4}{ }^{2-}
\end{aligned}
$$

\section{Optimization of loading step}

Loading of the uranyl sulfate ion complex, $\left[\mathrm{UO}_{2}\left(\mathrm{SO}_{4}\right)_{3}\right]^{4-}$, from aqueous phase of sulfate solution to organic phase of Alamine 336 required the investigation of several effective loading parameters as follow:

\section{Effect of Alamine 336 concentration}

Fig. (2) Shows the effect of Alamine 336 concentration upon $U$ extraction efficiency from the working sulfate solution of $\mathrm{pH} 0.5$. Four equilibrium experiments were conducted by using different Alamine 336 concentrations 
ranging from 1 to $5 \%$ in kerosene at $\mathrm{O} / \mathrm{A}$ volume ratio of $1 / 1$ and contact time of $5 \mathrm{~min}$. After separation, $\mathrm{U}$ was analyzed in the raffinate aqueous solution to calculate its extraction efficiency. The obtained data emphasized that Alamine 336 concentration has a great influence on $\mathrm{U}$ extraction efficiency which is progressively improved from 64.8 to $92.2 \%$ as the Alamine concentration increases from $1-2 \%$. It is also observed that further increase in the solvent concentration, more than $2 \%$, shows limit increase in U extraction efficiency.

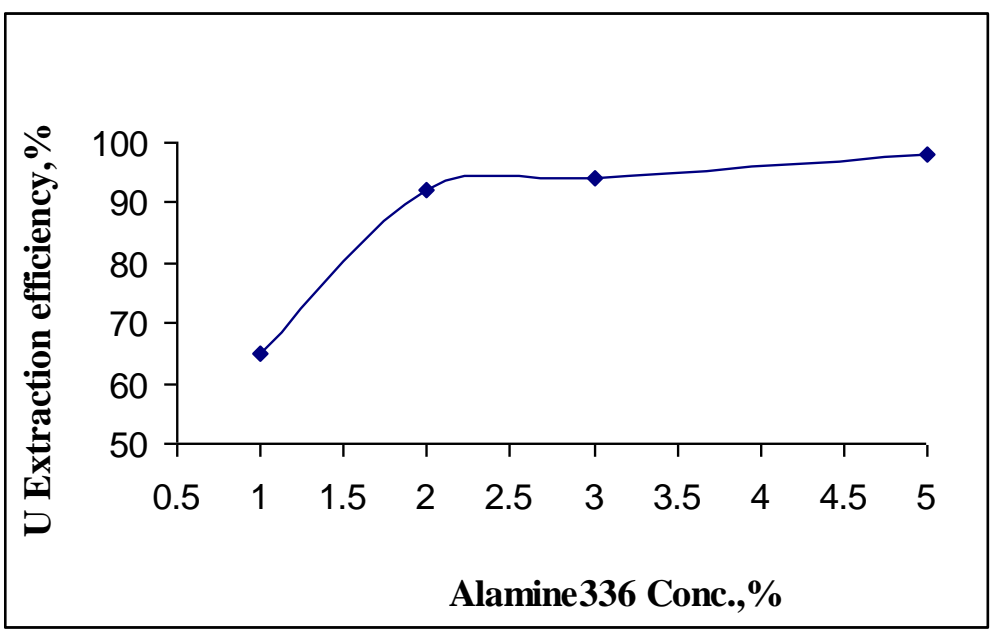

Fig. (2): Effect of Alamine 336 conc., \% upon U extraction efficiency, \%

\section{Effect of pH values}

The effect of $\mathrm{pH}$ values of the prepared sulfate solution upon $\mathrm{U}$ extraction efficiency, \% was studied in the range from 0.5 to 1.5 . The other parameters were kept constant at Alamine 336 concentration of $2 \%(\mathrm{v} / \mathrm{v})$ in kerosene, $\mathrm{O} / \mathrm{A}$ volume ratio of $1 / 1$ and contact time of $5 \mathrm{~min}$. Data shown in Fig. (3) revealed that the percentage of $U$ extraction efficiency increased from $92.2 \%$ to $97.6 \%$ with increasing the $\mathrm{pH}$ value of the sulfate leach liquor from 0.5 to 0.75 . While further increase in the $\mathrm{pH}$ values to 1 and 1.5 has an opposite effect, where $\mathrm{U}$ extraction efficiency deceased up to $73.3 \%$. This decrease in efficiency is due to the decreasing in the acidity of the working sulfate which inhibits quaternary liquid amines for $U$ uploading.

\section{Effect of contact time}

Figure (4) indicates the effect of contact time (shaking time) upon $U$ extraction efficiency from the working sulfate solution of $\mathrm{pH} 0.75$. The latter was mixed with $2 \%(\mathrm{v} / \mathrm{v})$ Alamine 336 in kerosene and shacked at different time periods ranging from 2 to $10 \mathrm{~min}$ at $\mathrm{O} / \mathrm{A}$ volume ratio of $1 / 1$. The resulted data clearly indicate that the \% extraction efficiency of $\mathrm{U}$ increases to its maximum value $(97.6 \%)$ at the contact time of $7 \mathrm{~min}$. It shows also that the $\%$ extraction efficiency of $\mathrm{U}$ did not affected by further contact time increasing up to $10 \mathrm{~min}$. This may be explained by achieving the organic solvent to its equilibrium capacity. 


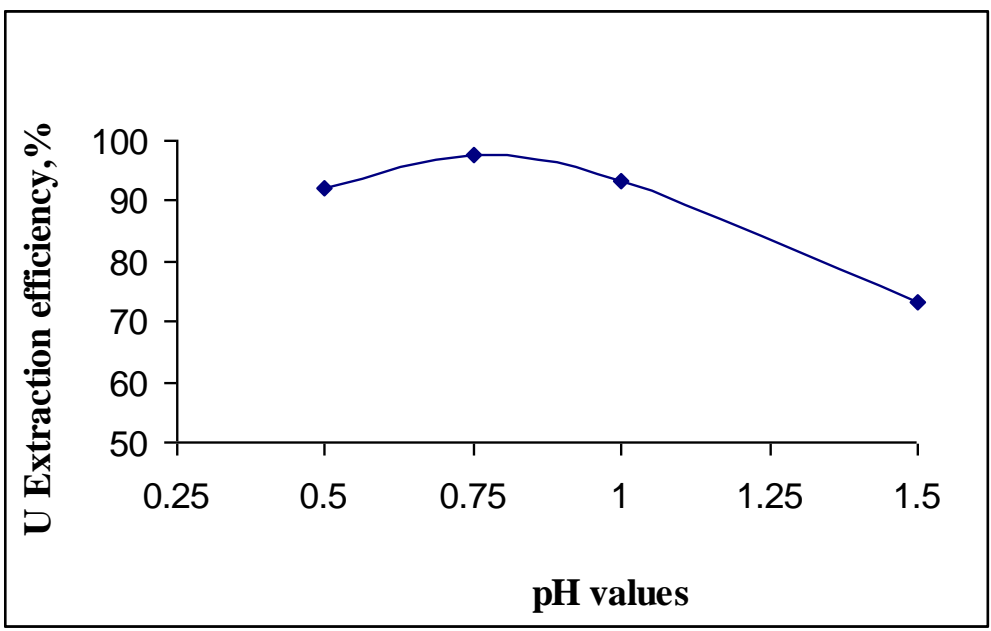

Fig. (3): Effect of $\mathrm{pH}$ values solution upon $\mathrm{U}$ extraction efficiency, \%

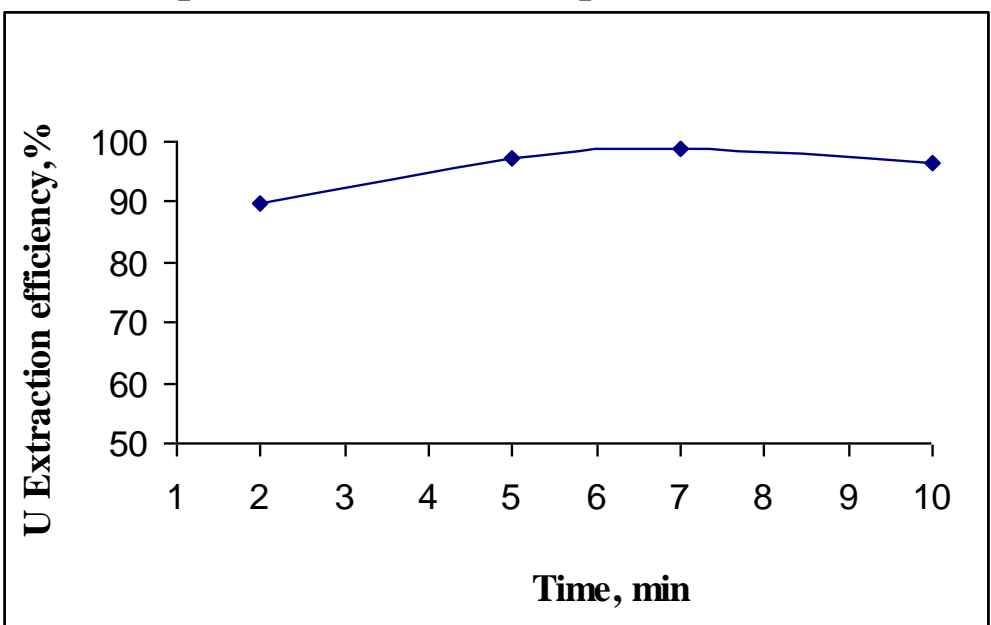

Fig. (4): Effect of contact time upon U extraction efficiency, \%

\section{Effect of (O/A) ratio, (McCabe Thiele diagram)}

The effect of different $\mathrm{O} / \mathrm{A}$ ratios upon $\mathrm{U}$ extraction efficiency was studied by contacting the present sulfate solution adjusted to $\mathrm{pH} 0.75$ with $2 \%(\mathrm{v} / \mathrm{v})$ Alamine $_{336}$ in kerosene at different $\mathrm{O} / \mathrm{A}$ ratios ranging from $2 / 1 \ldots 1 / 1 \ldots \ldots$ $1 / 2$ for a contact time of $7 \mathrm{~min}$. $U$ in the raffinate aqueous solution was analyzed after separation and its \% extraction efficiency was calculated and tabulated as given in Table (5). The obtained data indicated that although the $\mathrm{U}$ extraction efficiency at $\mathrm{O} / \mathrm{A}$ ratios of $2 / 1,2 / 1.5$ were 99 and $100 \%$, respectively and their distribution coefficients $D_{A}^{O}$ were 33.3 and $\infty$, respectively are higher than that of O/A ratio of 1/1 (98.7\%) and $D_{A}^{o} 44$, but these ratios are not applied because they give a diluted loaded $\mathrm{U}$ in the organic phase.

On the other hand, the $\mathrm{U}$ extraction efficiencies at $\mathrm{O} / \mathrm{A}$ ratios of $1 / 2$ and $1 / 1.5$ which were 84 and $92 \%$, respectively and their $D_{A}^{O}$ were 12.2 and 5.25, respectively. These O/A ratios were also not applied because they are lower 
than that of $1 / 1$. Indeed, the applied $\mathrm{A} / \mathrm{O}$ ratio was $1 / 1$ which was also economic to save the organic solvent. McCabe Thiele diagram, Fig. (5) shows that there are only two extraction stages required for almost extraction of $U$ from the prepared solution

Table (5): Effect of O/A volume ratio upon U extraction efficiency, \%

\begin{tabular}{ccccc}
\hline $\begin{array}{c}\text { O/A } \\
\text { ratio }\end{array}$ & $\begin{array}{c}\text { Aqueous phase } \\
\text { conc., ppm }\end{array}$ & $\begin{array}{c}\text { Organic phase } \\
\text { conc., ppm }\end{array}$ & $D_{A}^{o}$ & $\begin{array}{c}\text { U Extraction } \\
\text { efficiency, \% }\end{array}$ \\
\hline $1 / 2$ & 216 & 1134 & 5.25 & 84 \\
$1 / 1.5$ & 68 & 828 & 12.2 & 92 \\
$1 / 1$ & 10 & 440 & 44 & 97.6 \\
$1.5 / 1$ & 4.5 & 223 & 33.3 & 99 \\
$2 / 1$ & 0 & 150 & $\infty$ & 100 \\
\hline
\end{tabular}

From the above study, it could be concluded that the maximum $\mathrm{U}$ extraction efficiency of $98 \%$ from Abu-Hamata sandy claystone sulfate solution was achieved by using $2 \% \mathrm{v} / \mathrm{v}$ of Alamine 336 at $\mathrm{pH} 0.75$ and contact time of 7 $\mathrm{min}$ at $\mathrm{O} / \mathrm{A}$ ratio of $1 / 1$. By applying these conditions upon $500 \mathrm{~mL}$ of the working sulfate solution, it was found that $2 \%$ Alamine 336 in kerosene could uptake about $2000 \mathrm{mg}$ of $\mathrm{U}$ with achieved U extraction efficiency of $89 \%$. This could be attributed to the presence of interfering anions in the prepared sulfate solution e.g. $\mathrm{SO}_{4}{ }^{2-}, \mathrm{HSO}_{4}^{-}$and $\mathrm{Cl}^{-}$[Merrit (1971), Ritcy, et al., (1993) and Mackenzie (1997)]. The loaded solvent was then directed to the stripping step for recovering its loaded $\mathrm{U}$.

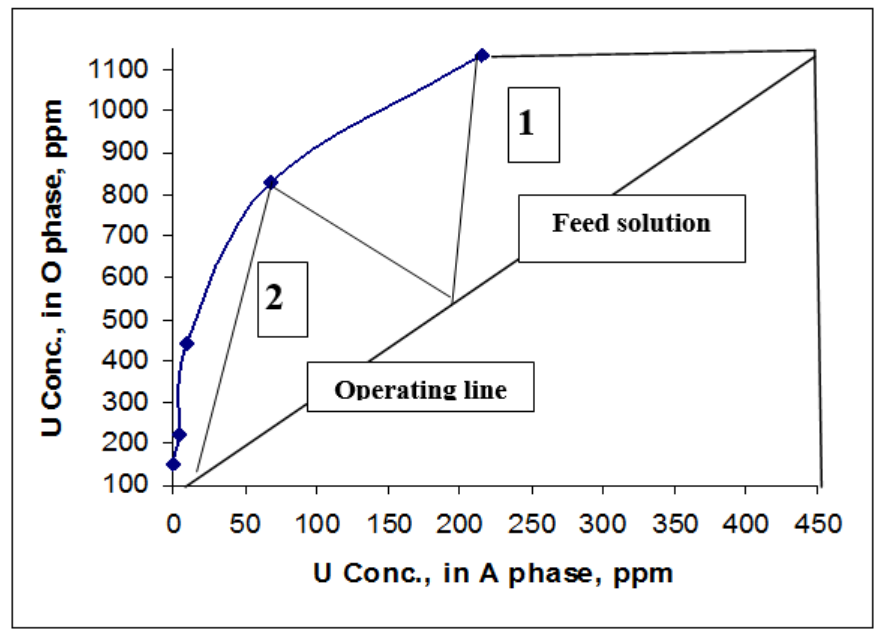

Fig. (5): McCabe Thiele diagram for extraction

\section{Optimization of the stripping process}

The stripping process is not only to regenerate the loaded organic solvent but also to obtain a $\mathrm{U}$ rich solution suitable to produce the preferred products. The 
stripping process of the loaded $U$ represented in equation. Different effective stripping parameters such as: type and concentration of stripping reagent, contact time and $\mathrm{O} / \mathrm{A}$ volume ratios were studied to attain the maximum $\mathrm{U}$ stripping efficiency.

$$
\left(\mathrm{R}_{3} \mathrm{NH}\right)_{4} \mathrm{UO}_{2}\left(\mathrm{SO}_{4}\right)_{3}+4 \mathrm{NaCl} \longrightarrow 4\left(\mathrm{R}_{3} \mathrm{NHCl}\right)+\mathrm{Na}_{4} \mathrm{UO}_{2}\left(\mathrm{SO}_{4}\right)_{3}
$$

\section{Effect of stripping reagent types.}

The loaded Alamine 336 was stripped with different stripping reagents such as: $5 \%\left(\mathrm{H}_{2} \mathrm{SO}_{4}, \mathrm{HCl}, \mathrm{HNO}_{3}, \mathrm{NaCl}\right.$ and $\mathrm{NaCl}$ acidified in $\left.0.2 \mathrm{M} \mathrm{H}_{2} \mathrm{SO}_{4}\right)$ at $\mathrm{O} / \mathrm{A}$ volume ratio of $1 / 1$ and contact time of $5 \mathrm{~min}$. After separation, $\mathrm{U}$ in the strip solution was analyzed and its \% stripping efficiency was calculated. The obtained data revealed that the maximum U stripping efficiency (93.9\%) was given by using the acidified $\mathrm{NaCl}$ in $0.2 \mathrm{M} \mathrm{H}_{2} \mathrm{SO}_{4}$ solution as the stripping solution. While the other reagents gave lower values as shown in Fig. (6).

\section{Effect of strip solution concentrations}

The of changing strip solution concentrations upon $\mathrm{U}$ stripping efficiency was conducted by mixing the loaded solvent with $\mathrm{NaCl}$ acidified in $0.2 \mathrm{M} \mathrm{H}_{2} \mathrm{SO}_{4}$ in different concentrations such as: $2.5,5,7.5$ and $10 \%$. The other stripping parameters were kept constant at $\mathrm{O} / \mathrm{A}$ volume ratio of $1 / 1$ and contact time of 5 min. Results represented by Fig. (7) clearly revealed that U stripping efficiency showed great improvement from 78 to $93.9 \%$ as the strip solution concentration increased from 2.5 to $5 \%$. On the other hand, further increase in strip solution concentration to 7.5 and $10 \%$ show slightly improvement in the $\mathrm{U}$ stripping efficiency which increased to 95.2 and $96.8 \%$, respectively. Indeed, a concentration of $5 \%$ of the strip solution was already chosen and improved with other parameters.

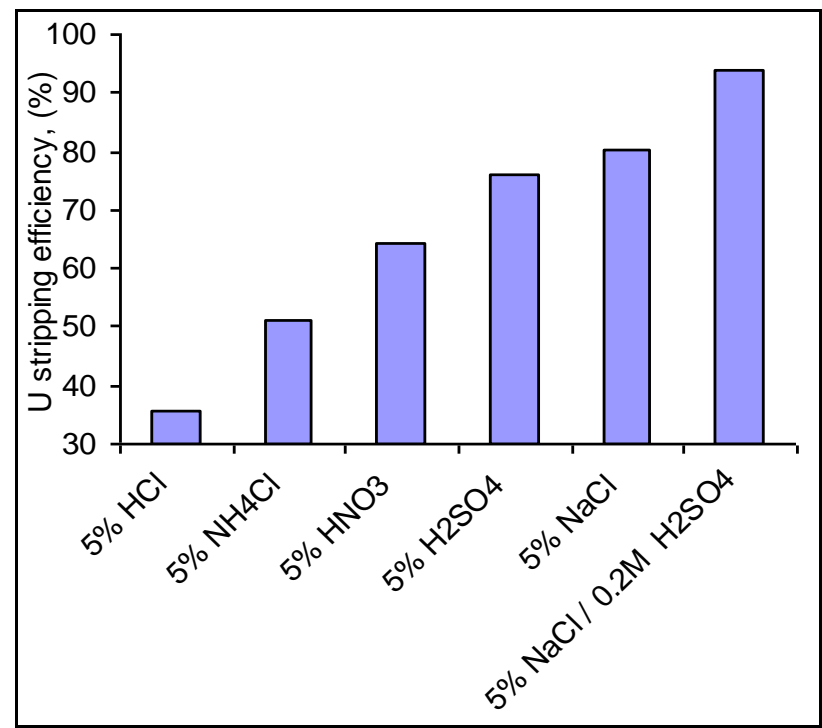

Fig. (6): Effect of reagents type upon U stripping efficiency, $\%$. 


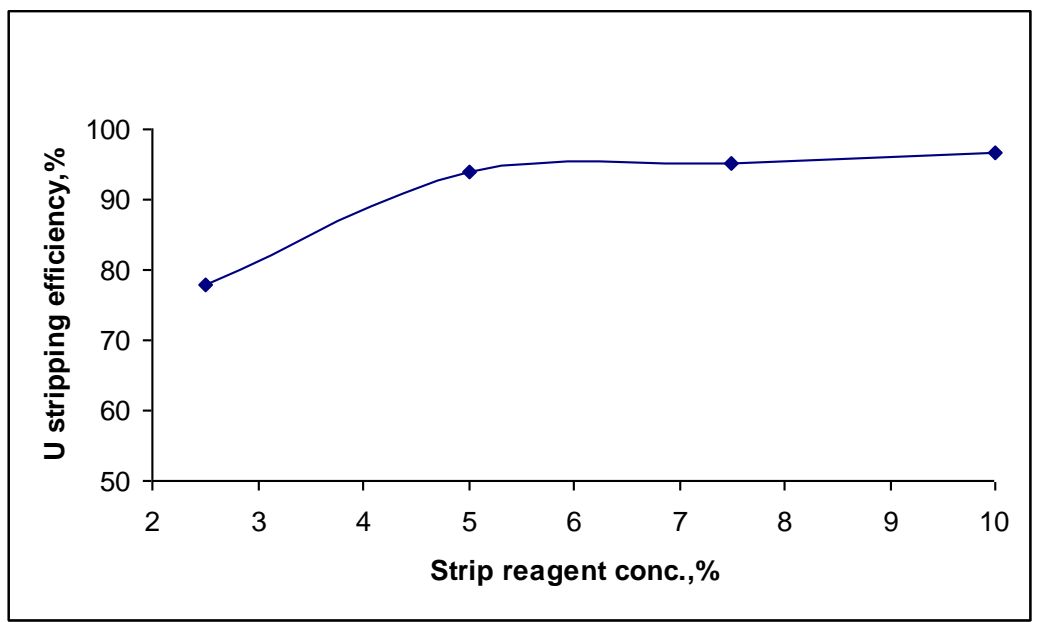

Fig. (7): Effect of reagent concentration on U stripping efficiency, \%

\section{Effect of contact time.}

The effect of contact time was performed by contacting the loaded solvent with the strip solution of $5 \% \mathrm{NaCl}$ acidified with $0.2 \mathrm{M} \mathrm{H}_{2} \mathrm{SO}_{4}$ at different contact period times varying from 2 to $7 \mathrm{~min}$ at $\mathrm{O} / \mathrm{A}$ volume ratio of $1 / 1$. It was actually noticed that, $\mathrm{U}$ stripping efficiency increased from 76.2 to $93.9 \%$ by increasing the reaction time from 2 to $5 \mathrm{~min}$. Further increasing in the reaction time to $7 \mathrm{~min}$ decrease $\mathrm{U}$ stripping efficiency to $78 \%$, Fig (8). The obtained data may be attributed to the transition of some $U$ sulfate complex again to the regenerated solvent by increasing the striping time.

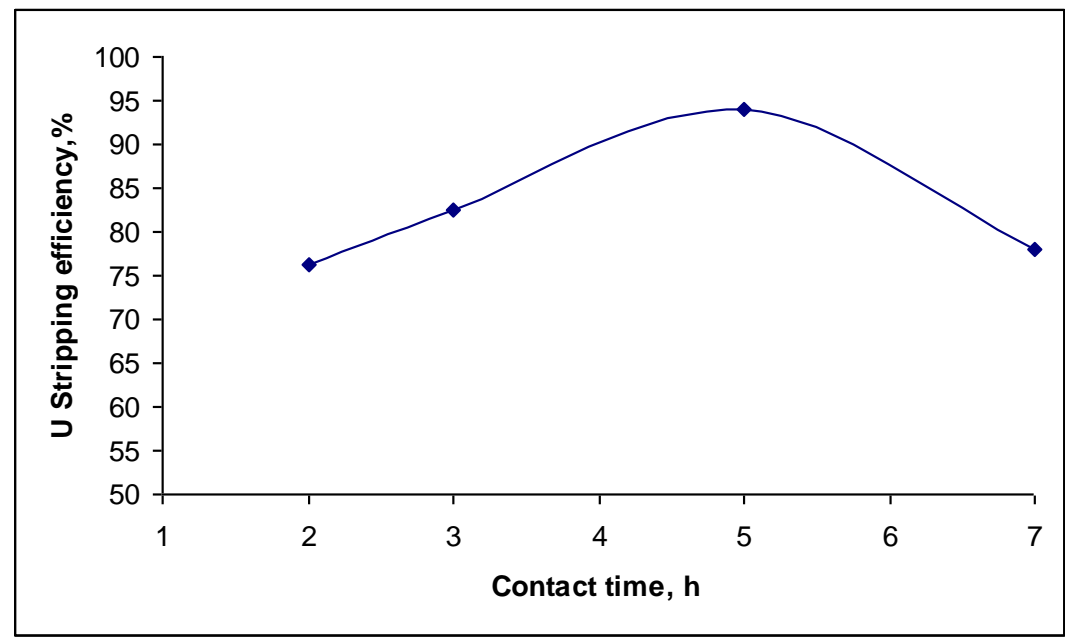

Fig. (8): Effect contact time upon U stripping efficiency, \%

\section{Effect of aqueous / organic (A/O) ratio.}

The stripping efficiency of $\mathrm{U}$ from the saturated loaded Alamine 336 using $5 \% \mathrm{NaCl}$ acidified with $0.2 \mathrm{M} \mathrm{H}_{2} \mathrm{SO}_{4}$ strip solution was investigated at different $\mathrm{O} / \mathrm{A}$ volume ratios ranged from $1 / 2 \ldots .1 / 1 \ldots .1 / 2$ by contacting for 
5min. After separation and analysis of $U$ in the strip aqueous solution, it was clearly observed that the almost loaded $\mathrm{U}$ was stripped with achieved stripping efficiency of $100 \%$ at O/A ratio of $1 / 2$ and reached $96 \%$ at O/A of $1 / 15$. These ratios were not applied because they yield $\mathrm{U}$ diluted solutions. On the other side, $\mathrm{U}$ stripping efficiency decreased to $63 \%$ and $72.2 \%$ at $\mathrm{O} / \mathrm{A}$ ratios of $2 / 1$ and 1.5/1, respectively, (Table $10 \&$ Fig. 9). These ratios were also not applied because they are lower than the $\mathrm{U}$ stripping efficiency at $\mathrm{O} / \mathrm{A}$ ratio of $1 / 1,(93.9 \%)$ which was the ideal for application.

Table (10): Effect of O/A volume ratio upon U stripping efficiency, \%

\begin{tabular}{ccccc}
\hline O/A ratio & Conc., (O), ppm & Conc., (A), ppm & $D_{O}^{A}$ & $\begin{array}{c}\text { U Stripping } \\
\text { efficiency, } \%\end{array}$ \\
\hline $2 / 1$ & 800 & 4800 & 6 & 63 \\
$1.5 / 1$ & 720 & 4380 & 6.08 & 72.2 \\
$1 / 1$ & 268 & 3932 & 14.67 & 93.9 \\
$1 / 1.5$ & 160 & 2960 & 18.5 & 96 \\
$1 / 2$ & 0 & 2000 & $\infty$ & 100 \\
\hline
\end{tabular}

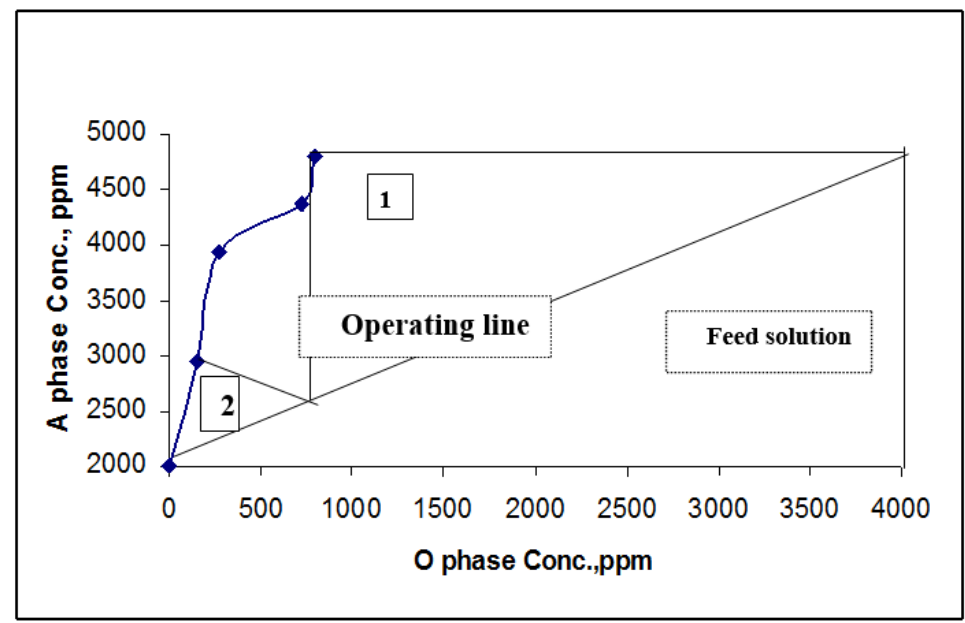

Fig. (9): McCabe Thiele diagram for stripping.

From the forgoing study, $\mathrm{U}$ was almost transfered to the aqueous soltion with an achieved $\mathrm{U}$ stripping efficiency of $93.9 \%$ by using $5 \% \mathrm{NaCl}$ solution acidified with $0.2 \mathrm{M} \mathrm{H}_{2} \mathrm{SO}_{4}$ and stripping time of $5 \mathrm{~min}$ at $\mathrm{O} / \mathrm{A}$ ratio of $1 / 1$.

\section{Preparation of pure $\mathrm{U}_{3} \mathrm{O}_{8}$}

The obtained $\mathrm{U}$ rich strip solution which assays $4.1 \mathrm{~g} / \mathrm{L}$ of $\mathrm{U}$ was then treated with $\mathrm{H}_{2} \mathrm{O}_{2}$ solution for precipitating its $\mathrm{U}$ content as uranyl hydroxide, $\mathrm{UO}_{2}(\mathrm{OH})_{2}$ with an achieved precipitation efficiency of $99 \%$. The optimum precipitation conditions are $\mathrm{pH} \mathrm{1,} \mathrm{stirring} \mathrm{time} \mathrm{period} \mathrm{of} 3 \mathrm{~h}$ at a temperature ranged from 20 to $25^{\circ} \mathrm{C}$, (Merritt, 1971; Shabbir and Tame, 1974; Gupta et 
al., 2004). After filtration and washing, the precipitated U hydroxide cake was ignited at $850^{\circ} \mathrm{C}$ for $1 \mathrm{~h}$ to be crystallized. The produced $\mathrm{U}_{3} \mathrm{O}_{8}$ was washed, dried and directed to identification by using XRD analysis technique as shown in Fig (10). The chemical analysis of the final product of $\mathrm{U}_{3} \mathrm{O}_{8}$ showed that it had a purity of $98.5 \%$ with impurities such as: $0.2 \%$ of $\mathrm{Cl}^{-}, 0.13$ of $\mathrm{SO}_{4}{ }^{2-}, 0.1 \%$ of $\mathrm{Fe}$, and $0.06 \%$ of $\mathrm{V}$. The precipitation process is illustrated in equations:

$\mathrm{UO}_{2} \mathrm{Cl}_{2}+\mathrm{H}_{2} \mathrm{O}_{2} \rightarrow \mathrm{UO}_{2}(\mathrm{OH})_{2}+2 \mathrm{HCl}$

$\mathrm{UO}_{4} .2 \mathrm{H}_{2} \mathrm{O}$ ignition $/ 850^{\circ} \mathrm{C} / 1 \mathrm{~h} \rightarrow \mathrm{U}_{3} \mathrm{O}_{8}+\mathrm{H}_{2} \mathrm{O}$

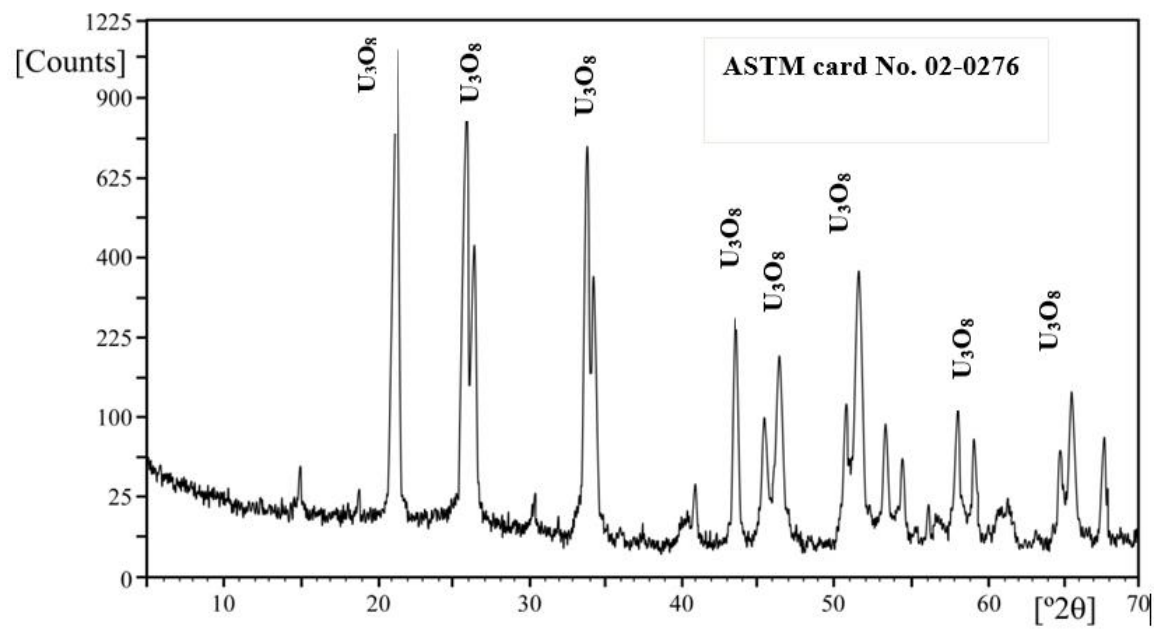

Fig. (10): XRD pattern for the identification of pure $\mathrm{U}_{3} \mathrm{O}_{8}$

\section{Conclusions}

The potentiality of preparing highly pure $\mathrm{U}_{3} \mathrm{O}_{8}$ from sulfate solution of $\mathrm{Abu}$ Hamata sandy clay stone ore material assaying $0.45 \mathrm{~g} / \mathrm{L}$ of $\mathrm{U}$ has been attained via solvent extraction process. Alamine 336 was used for extracting $97 \%$ this purpose at $\mathrm{O} / \mathrm{A}$ volume ratio of $1 / 1$, contact time of $7.5 \mathrm{mim}$ and $\mathrm{pH} 1$. More than $93 \%$ of the loaded $\mathrm{U}$ was already stripped and transferred to the aqueous

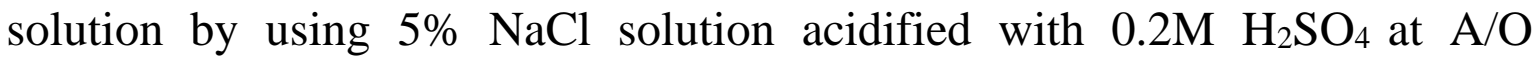
volume ratio of $1 / 1$ and stripping time of $5 \mathrm{~min}$.

Not less than $99 \%$ of $\mathrm{U}$ in the obtained strip solution was precipitated as $\mathrm{UO}_{2}(\mathrm{OH})_{2}$ by using $\mathrm{H}_{2} \mathrm{O}_{2}$ solution at $\mathrm{pH} 1$, stirring time of $3 \mathrm{~h}$ at a temperature ranged from 20 to $25^{\circ} \mathrm{C}$. The obtained uranyl hydroxide cake was ignited at $850{ }^{\circ} \mathrm{C}$ to produce $\mathrm{U}_{3} \mathrm{O}_{8}$ of achieved purity of $98.5 \%$. 


\section{References}

Abdel Monem, A.A., El-Assay, I., Hegab, O.A. El-Fayoumy, I.F. and El Agami, N., (1997): Gibbsite, uranium and copper mineralization, Um Bogma area, Southweatern Sinai, Egypt, J. of Sedimentology, of Egypt, Vol. 5, pp117-132

Al Shami, A.S. (2003): Structural and Lithologic controls of $\mathrm{U}$ and $\mathrm{Cu}$ mineralization of Um Bogma Evirons, Southwestern Sinai, Egypt, Ph.D. Thesis, Geology Department, Faculty of Science, Mansura University, Mansura, Egypt.

Amaral, J. C., and Morais, C. A., (2010): (Th and U extraction from rare earth elements in monazite sulfuric acid liquor through solvent extraction)), J., Minerals Engineering, 23, pp 498-503.

Amer, T.E., (1993): Physical and chemical studies on the U-Cu mineralization of uraniferous Paleozoic sediments, West central Sinai, Master Thesis, Geology Department, Faculty of Science, Cairo University, Cairo, Egypt.

Amer, T.E., (1997): Geochemistry and extraction of $\mathrm{U}, \mathrm{Cu}$ and $\mathrm{Mn}$ from the ore material of the uraniferous Paleozoic sedimentary rocks, West central Sinai, Egypt, Ph.D. Thesis, Geology Department, Faculty of Science, Cairo University.

Bhowmik, K.A., Shanmugavelu, P., Dhvamuri, D. and Agrawal, A. (2009): Single stage purification of $U$ refining, World Intellected Property Organization, International Bureau, International Publication No.Wo.2009/013759 A (PCT).

Dabbour, G. M. and Mahdy, M. A. (1988): Mineralogical studies on the carboniferous sediments of west central Sinai, Egypt, 4 th Conf., Nucl.Sci. and Appl., Egypt, pp.230-237.

Dahlkamp, F.J. (1980): (Typology and Geographic/Geotectonic Distribution of uranium Deposits)', In Energy Resources Barollet P.F. and Zigler V.eds, pp. 499-536.

Ghonaim, A. E., El-Hazek, N. T, Ahmed, F. Y., and Abedel Fattah, N. A. (2004): "Acid leaching and recovery of the metal values of the gibbsite bearing Um Bogma Formation West Central Sinai, Egypt", Al-Azhar Bull. Sci,Vol. 51, P.29-42.

Gupta, R., Pandey, V.M., Pranesh, S.R. and Chakravarty, A.B. (2004): Study of an improved technique for precipitation of uranium from eluted solution, Hydrometallurgy, 71, (3-4), P. 429-434.

Hussein, H.A., Abdel Momen, A.A., Mahdy, M.A., El Aassy, I.E., and Dabbour, G.A. (1992): On the Gensis of Surficial U occurences in West 
central Sinai, Egypt, Ore Geo. Rev.7, El-Sevier Sci.Publ., B.V, Amsterdam, P.125-134.

Kumar J. R., Kim, J. SA., Lee, J. Y., Yoon, H. S., (2010): Solvent extraction of $\mathrm{U}$ and separation of $\mathrm{V}$ from sulfate solutions using Alamine 336, Radioanal. Nucl. Chem, 285, pp 301-308.

Mackenzie, J. M. W., (1997): Uranium solvent extraction using tertiary amines. U ore yellow cake Seminar Feb. Melbourne, Australia.

Marczenko, Z. (2000): "Spectrophotometric determination of elements", John Wiley and Sons, Harwood, New York.

Mathew, K.J., Burger, S., Ogt, S.V., Mason, P.M. and Narayanan, U.I (2009): Uranium assay determination using Davies and Gray titration. Processing the Eighth International Conference on Methods and Applications of Radioanalytical Chemistry (Marc Viii) Kaailua-Kona, Hawaii, P.5.

Merritt, R.C. (1971): The Extractive Metallurgy of Uranium, Colorado School of Mines Research Institute, United States Atomic Energy Commission.

Ramadevi, G. Sreenivas, T. Navale, A. and Padmanabhan, N. (2012): (Solvent extraction of uranium from lean grade acidic sulfate leach liquor with alamine 336 reagent)' J., Rad.1 Nucl Chem., 294, pp13-18.

Ritcy, G.M. and Ashrock, A.W. (1982): A comparison of the processing and economics of uranium recovery from leach slurries by continuous ion exchange or solvent extraction "Hydrometallurgy (Proc. Int. Symp. Chicago, 1973), American Institute of Mining, Metallurgical and Petroleum Engineer, New York.

Ritcy, G.M., Ring, R. J., Roche, $M$ and Ajuria, S., (1993): Uranium extraction technology. Technical Reports Series No., 359, International Atmic Energy Agency, Vienna, Dec. p. 355.

Shabbir, M. and Tame, K.E. (1974): Hydrogen peroxide precipitation of U, US Bureau of Mines, USA, RI 7931.

Shapiro, L. (1975): "Rapid Analysis of Silicate, Carbonate and Phosphate Rocks, Revised Edition, U.S Geological. Survey. Bulletin., Washington. 
استخلاص اليورانيوم باستخدام اللامين 336 فى الكيروسين من محلول الكبريتات الخاص بخام الطين الرملى منطقة ابوحماطةـ جنوب غرب سيناء- مصر 1 جلال محمود عبدالوهاب و1 وليد محمود عبداللاه 2 محمد فتحى الثحات 1 هيئة المواد النووية 2 كلية العلوم جامعة عين شمس العودة

هذه الدراسة تهنم بامكانية استخدام المذيب العضوى باستخدام الالامين 336 فى الكيروسين فى استخلاص اليور انيوم من محلول الاذابة الكبريتى الخاص بخام الطين الرملى منطقة ابوحماطة جنوب

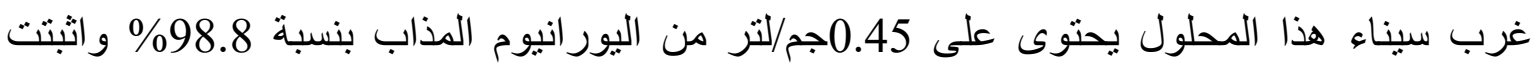

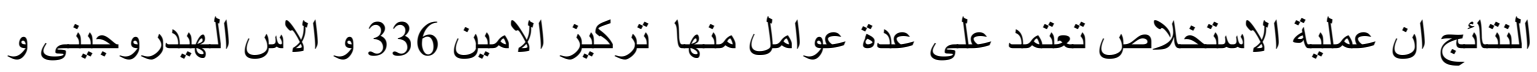
زمن الخلطو نسبة الخلط الدذيب و المحلول . اليور انيوم المحمل فى المذيب يتم استرجاعه بواسطة محلول 1 مولر كلوريد الصوديوم المحمض وله

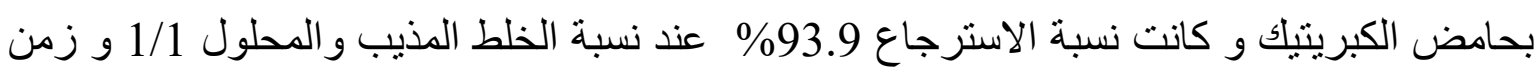
الخلط 5 دقائق ـ تم ترسيب 99\% من اليور انيوم المسترجع بواسطة محلول فوق اكسيد الهيدروجين

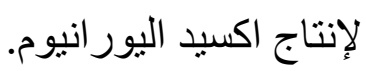

